\title{
How do you say Istanbul Protocol in Hebrew? The case of Mr Firas Tbeish
}

\author{
Efrat Shir*
}

On 26 of November 2018, Israel's High Court of Justice decided that Mr Firas Tbeish had not been tortured. This concluded a six-year legal battle undertaken by $\mathrm{Mr}$ Tbeish and the Public Committee Against Torture in Israel (PCATI).

This case review presents some of the complexities which on-the-ground anti-torture work in Israel entails. Specifically, it touches upon the seeming effortlessness with which a recognised international standard such as the Istanbul Protocol (IP; UN OHCHR, 2004) can, and is, dismissed, at the same time dismissing the experience of persons tortured. As always, local context is important. Israel does not have an official position on the IP, and the state does not utilise the IP to examine allegations of torture. On a broader scale, while torture is outlawed based on a High Court of Justice ruling, and while Israel has signed and ratified the Convention Against Torture, it has never criminalized torture per se in domestic legislation, and has no mechanism to screen or identify victims.

And so, while the court's conclusion was hardly surprising, the reasoning behind the decision, and the court's disregard of the IP, was nonetheless... disturbing.

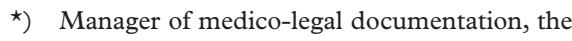
Public Committee Against Torture in Israel Correspondence to: efrat.shir@stoptorture.org.il

\section{Who is Mr Tbeish?}

A Palestinian from the Hebron area in the West Bank, Mr Tbeish was a member of the Hamas organisation when he was arrested by Israel and put under administrative detention in November 2011. In his mid-thirties at the time, this was neither his first nor second such arrest; the practice is common in Israel, which detains Palestinians without trial for periods of 6 months to 3 years (as of July 2019, 454 Palestinians were known to be held in administrative detention; B'Tselem, 2019). At the beginning of September 2012, after nearly 10 months of administrative detention, Mr Tbeish was subject to a security interrogation undertaken by the Israeli Security Agency (ISA), an interrogation that lasted in one form or another for over a month.

\section{The interrogation at the heart of this case}

Some facts regarding what took place are not disputed: For nearly a week, $\mathrm{Mr}$ Tbeish was continuously transferred between various detention facilities; he was denied access to legal counsel for 28 days; "exceptional interrogation techniques" were

\footnotetext{
The author would like to greatly thank Dr Rachel Stroumsa for reading and commenting on previous versions.
} 
used on him; he vomited in his interrogation and complaints as to his treatment were recorded in medical and Military court records; he signed a confession; and following his interrogation the army seized a Hamas ammunition dump.

Was Mr Tbeish tortured? PCATI says yes. According to Mr Tbeish's own account, and based on the limited external documentation made available to the organisation, PCATI argued that he was shuttled for no apparent reason between detention facilities for seven days while shackled, which drained him physically and mentally. He was subject to extreme sleep deprivation for long periods, including six consecutive days without regular sleep, his interrogation sessions began at 8 in the morning and lasted till dawn the next day with only three 20 -minute cell breaks; and his interrogation included threats, curses and complete isolation. The "exceptional interrogation techniques," employed over three days indicating he was classified as a "ticking bomb," comprised stress positions, beating, and other forms of physical violence in addition to psychological pressure. For example, this is how he described the "banana":

"No one could be in the chair, tied in the banana position for more than 3 to 5 minutes. After that they pick you up for 30 seconds and then lower you again. I cannot say for how long they did that to me... hours... hours in which you are bent down, bent up, asked again, bent down... The level of pain is more than a human being can resist... I was put beyond all limits... During this situation I fainted... Sometimes they [prison guards] poured water [over me].”

(It is worth noting that while the use of stress positions, sleep deprivation and other components of the "exceptional interrogation techniques" set are regarded as torture and outlawed in international law - at times on their own and at times in conjuncture with other acts-Israel does not view them as such.)

\section{The medical aspects}

As a result of his interrogation MrTbeish suffered from scotoma in his left eye due to a direct punch, which is still present, pain and paraesthesia along the entire left leg, and epigastric pain. He also testified to vomiting and losing consciousness more than once during his interrogation, though this was disputed by the court. In the meagre medical file, four physical examinations by physicians working with the Israel Prison Service are recorded during the three days in which "exceptional means" were used, in which pain in the right molar, bilateral swelling of the knees, swelling and pain with palpitation, and limited movement of the left knee were recorded, as well as a medical record of "bloodshot eyes, did not sleep tonightinterrogation". None of the records elaborate on the cause of the findings. Disturbingly, some of these examinations were carried out in the interrogation room itself.

\section{Torture in Israel}

Much has been written about the concept of the "ticking bomb scenario" and the use of torture (e.g., Luban, 2005; Shue, 2006; Sussman, 2005). Israel's ISA interrogations and legal mechanisms have similarly received attention from professional bodies and academics alike (e.g., Bergman-Sapir, 2016; Chachko 2018; Kremnitzer \& Shani, 2018). For our purpose, it is important to note that Israel ratified the Convention against Torture in 1991 but has neither outlawed nor defined torture in domestic legislation. However, the country's High Court of Justice prohibited the use of torture in its now famous 1999 
ruling (Public Committee Against Torture v State of Israel), finding that "a reasonable investigation is necessarily one free of torture, free of cruel, inhuman treatment, and free of any degrading conduct whatsoever," and outlawing shaking, the "Shabach" and "frog" methods, and sleep deprivation when used for reasons other than the needs of the interrogation. However, the High Court of Justice also left the door open for the State Attorney General to establish his or her own guidelines in regard to security interrogations. These confidential guidelines include the instances in which interrogators will be exempt from criminal prosecution-as long as their practices do not amount to torture, which has not been further construed. The debate in Israel is circumscribed by this ruling and these guidelines, and takes place in a narrow arena: Given certain acts took place, do they constitute torture-which is forbidden, in theory, though undefined-or are they legitimate, if extreme, interrogational techniques? In effect, there is a loophole into which complaints of torture and ill-treatment fall, and through which are almost always dismissed. That is, if the allegations are believed in the first place. Mr Tbeish's case exemplifies this.

\section{The legal process}

Was a lengthy one. A complaint of torture was submitted by PCATI on Mr Tbeish's behalf in April 2013. His testimony was taken by the responsible state investigator in August 2014 and again in January 2015, more than 26 months after his interrogation ended. The final decision of the High Court of Justice was published nearly 47 months later (Firas Tbeish et al. v the State Attorney General et al.). And yet, despite the prolonged examination process and the thousands of working hours and documents, the result was a dismissal.

\section{The burden of proof}

\author{
"In their arguments, the Petitioners have \\ focused on the component of "pain or \\ suffering, whether physical or mental" \\ caused to the Petitioner, according to his \\ claims, during his interrogation, as a \\ result of the violence used against him by \\ his interrogators... \\ The Petitioners believe that there is \\ "objective real-time evidence of pain \\ and suffering" supporting the Petitioners' \\ version.... Contrary to the Petitioners' \\ arguments, I do not believe that all \\ of the above is sufficient to prove the \\ Petitioner's version." \\ [Firas Tbeish et al. v the State Attorney General \\ et al., paras 47-50]
}

But, how does one prove one's "version"? In a reality in which interrogations are not recorded, medical files are lacking and interrogees' rights frequently ignored, how could Mr Tbeish have proven that what he claims happened really did take place? And how can his claim that these acts caused him great pain and suffering be established?

As is too often the case, the interpretation of the severity of pain and suffering was the legal hinge on which $\mathrm{Mr}$ Tbeish's account hung - whether he was tortured or simply subjected to "exceptional interrogation means," which according to the established legal convention in Israel, do not rise above the legal and personal tolerable levels of pain and suffering, and hence do not amount to torture. (On a side note, it is worthwhile mentioning that the court ignored the possibility that $\mathrm{Mr}$ Tbeish was subjected to cruel, inhuman or degrading treatment if not torture, though this was claimed in the petition.)

To substantiate the claims of torture, PCATI initiated two expert IP assessments. 
The first was written by a physician who met $\mathrm{Mr}$ Tbeish in prison for a relatively short time in 2013, four months after his interrogation ended. A second IP assessment was carried out in December 2017, after Mr. Tbeish's release from prison. An experienced Israeli clinical psychologist and an international IP expert, a psychiatrist, met and interviewed Mr Tbeish for over eight hours on a mild winter day in a West Bank location accessible for both Palestinians and Israelis. This second report focused more heavily on the mental and emotional consequences of the interrogation, and explored in-depth the aspects of the interrogation that are difficult to define and document, and thus are readily dismissedthe threats, the isolation, the lack of sleep.

\section{The Court, the State and the Istanbul Protocol}

The court's decision was handed down in November 2018. The first IP opinion, from 2013, was given low evidentiary weight because it — apparently—failed to substantiate Mr Tbeish's medical complaints through a medical examination-though it did find his narrative credible and the physical findings consistent with his story. Yet it was the court's stance on the second opinion that was the more surprising:

“... this medical opinion was prepared on 14.12.2017, over five years following the Petitioner's interrogation, and it is almost completely based on the Petitioner's version. Obviously, these two factors greatly weaken its evidential value, and in fact it cannot be given any real weight, nor can it be determined that any connection exists between its findings concerning the Petitioner's physical, cognitive and emotional condition, and the manner of his interrogation, as described by him in his complaint.” [para 56, emphasis added]

It is probably useful to point out here that the IP and its practical manifestations are regarded as a "strange creature" in Israel. The country does not have an official position on the IP. It does not utilise this tool to examine allegations of torture, nor does the state independently train its own investigators and judges in its light, despite recommendations by governmental commissions to do so (The Turkel Commission, 2010; The Ciechanover Commission, 2015). This fact has not gone unnoticed by the UN Committee Against Torture, which recommended that "all relevant staff, including medical personnel, are specifically trained to identify and document cases of torture and ill-treatment in accordance with the Istanbul Protocol" (UN Committee Against Torture, 2016, para 50). IP reports previously submitted by PCATI have been dismissed by the state body responsible for examining complaints of torture as redundant, or have simply been ignored, though no opposing expert opinions were presented. The state's decision to dismiss Mr Tbeish's complaint, from September 2016 states:

"There is no evidence in the case documents that the complainant lost consciousness, or that the complainant incurred any physiological or psychological harm as a result of his arrest or interrogation by the ISA. There is nothing in the medical records presented to us, nor in the medical opinion of Dr F.A., to alter this conclusion."

\section{The Court and the Istanbul Protocol - Take II}

This disparaging view of the IP has been advanced by the High Court of Justice 
before, notably, in its decision in the case of Mr As'ad Abu Gosh, from December 2017 (As'ad Abu Gosh et al. v the Attorney General et al.). This PCATI petition was supported by an IP report written by two physicians and a clinical psychologist who twice interviewed the petitioner-who was interrogated by the ISA in 2007 . Though the opinion found consistency between the severe physiological and psychological findings and the account of the harsh and prolonged interrogation, and although no counteropinion was presented, the court dismissed its evidentiary weight, again noting:

"One must deduct from the evidential weight of the expert opinion also in view of the time which had passed since the Petitioner's interrogation until his examination by the experts. More than 5 years had elapsed, which is significant. This is all the truer when one notes the lack of medical records in the Petitioner's case." [paras 27-28, emphasis added]

This stated lack of medical records from the time of the interrogation, a frequent occurrence in PCATI's experience, was the primary ground for dismissing the physiological findings of the experts, which included findings of neurological damage attributed to the interrogation. The psychological findings were ignored by the court-a reoccurring phenomenon in a system that overtly views torture as physical and expects visible damage - and unfortunately, no mention of these can be found in the decision.

The court went further:

"One does not dispute the claim that the expert opinion is based on the Petitioner's statements at that point, close to his release from prison, and even the representative of the Petitioners has agreed that it is not identical to the first complaint submitted... This gap faults the weight of the expert opinion to a large extent. This holds even if some of the Petitioner's complaints to the writers of the expert opinion had been put forward by him earlier, and even if the writers were aware of this gap and gave an explanation for it..." [para 25, emphasis added]

And, though the IP opinion was discussed at length during a court hearing - the link between the narrative and findings considering the time passed between the interrogation and the evaluation, the more detailed descriptions in the medico-legal opinion, and the IP's international standingthis was not reflected in the decision:

"According to the experts, "the torture" which the Petitioner recounted "may" be a cause for the medical diagnosis, while the existence of a causal connection between the two is "reasonable to a large extent". In reference to this conclusion of theirs, one should note that the experts cannot determine whether the interrogative means used in the Petitioner's interrogation amounted to torture by the Convention, in spite of their training in the field of documentation of torture."

And so, the question remains and continues to be avoided: If an IP assessment is not significant, how can claims that interrogational methods cause great pain and suffering be established?

\section{The Istanbul Protocol in Israel- Concluding remarks}

An attitude of suspicion of the unfamiliar was visible in the justices' facial expressions when Mr Tbeish's IP report was introduced in the hearing. Indeed, following the High Court of Justice decisions, PCATI finds 
itself at a professional crossroads. On one side is the IP, a tool we believe in and struggle to introduce into Israel. On the other is a legal system that discredits the IP's potential while digging deeper into its own conception of torture. In the current context, should we continue advocating for the IP and its medico-legal reports, even though a legal brick wall awaits us?

Mr Tbeish was not surprised when the High Court of Justice decision in his case was made public. He too knew that of over 1,200 complaints of torture that have been submitted over nearly two decades, no ISA interrogator has ever been indicted. Yet, he was content that his story was documented, heard and asserted, even though not believed in court. And so, while we are debating internally - and on these pages - the most effective and appropriate IP strategies, this principle remains: There is great value in hearing a victim's story; there is worth in facilitating its broadcast to the wider world, beyond the walls of the interrogation room, regardless of the interrogee's identity.

\section{References:}

Bergman-Sapir, E. (2016, Nov. 15) A Veil over Torture: Israel's “Necessity Defense", OMCT. Retrieved from http://blog.omct.org/veil-tortureisraels-necessity-defense/

B'Tselem: The Israeli Information Center for Human Rights in the Occupied Territories (2019, August 12) Statistics on Administrative Detention. Retrieved from https://www.btselem.org/ administrative_detention/statistics

Chachko, E. (2018, Dec. 6) Tabish v. Attorney General and the Legal Framework Governing Physical Coercion in ISA Interrogations, Lawfare. Retrieved from https://www.lawfareblog.com/ tabish-v-attorney-general-and-legal-frameworkgoverning-physical-coercion-isa-interrogations

Kremnitzer, M. \& Shani,Y. (2018) The Absolute Prohibition of Torture and CIDT: A Dream or Reality - Israeli Law and Special Interrogation Techniques. Retrieved from https://idclawreview. files.wordpress.com/2018/12/KremnitzerShany. pdf (In Hebrew)
Luban, H. (2006) Liberalism, Torture, and the Ticking Bomb, VA. L. Rev., 91, 1425-1461. doi: 10.1007/978-1-4020-4678-0_15

Shue, H. (2006) Torture in Dreamland: Disposing of the Ticking Bomb, Case W. Res. F. Int'l L., 37(2), 231-239.

Sussman, D. (2005) What's Wrong with Torture? Philosophy and Public Affairs, 33(1), 1-33

The Ciechanover Commission (Team for the Review and Implementation of the Second Report of the Public Commission for the Examination of the Maritime Incident of May 31st 2010 Regarding Israel's Mechanisms for Examining and Investigating Complaints and Claims of Violations of the Law of Armed Conflict According to International Law) (2015) Report. Retrieved from: http://www.pmo.gov.il/ Documents/ReportEng.pdf

The Turkel Commission (The Public Commission to Examine the Maritime Incident of 31 May 2010) (2013) - Second Report: Israel's Mechanisms for Examining and Investigating Complaints and Claims of Violations of the Laws of Armed Conflict According to International Law. Retrieved from https://www.gov.il/BlobFolder/generalpage/ alternatefiles/he/turkel_eng_b1-474_0.pdf

UN Committee Against Torture (CAT) (2016) Concluding observations on the fifth periodic report of Israel, CAT/C/ISR/CO/5. Retrieved from https://tbinternet.ohchr. org/_layouts/15/treatybodyexternal/Download. aspx? symbolno $=\mathrm{CAT} / \mathrm{C} / \mathrm{ISR} / \mathrm{CO} / 5 \& \mathrm{Lang}=\mathrm{En}$

UN Office of the High Commissioner for Human Rights (OHCHR) (2004) Manual on the Effective Investigation and Documentation of Torture and Other Cruel, Inhuman or Degrading Treatment or Punishment ("Istanbul Protocol”), HR/P/PT/8/Rev.1. Retrieved from https:/www.ohchr.org/Documents/Publications/ training8Rev1en.pdf

Cases:

As'ad Abu Gosh et al. v the Attorney General et al., HCJ 5722/12 (2017). Retrieved from http:// stoptorture.org.il/wp-content/uploads/2017/02/ English-Translation-of-Abu-Ghosh-Judgment.DRAFT.odt.pdf

Firas Tbeish et al. v the Attorney General et al., HCJ 9018/17 (2018). Retrieved from http:// stoptorture.org.il/wp-content/uploads/2017/02/F.Tbeish-Ruling-Nov.-2018.ENG_.pdf

Public Committee Against Torture v State of Israel, HCJ 5100/94 (1999). Retrieved from https://supremedecisions.court.gov.il/Home/ Download?path=EnglishVerdicts $\backslash 94 \backslash 000 \backslash 051 \backslash$ a09\&fileName=94051000_a09.txt\&type $=4$ 